\title{
Relationship between thermal comfort indices and internal temperature of grazing lactating Holstein $x$ Gyr cows in western Amazonia
}

\author{
Giovanna Araújo de CARVALHO ${ }^{1}$, Ana Karina Dias SALMAN²*, Pedro Gomes da CRUZ², \\ Francyelle Ruana Faria da SILVA ${ }^{3}$, Jéssica HALFEN ${ }^{4}$, Eduardo SCHMITT ${ }^{5}$ \\ Universidade Federal de Rondônia - UNIR, Programa de Pós-graduação em Desenvolvimento Regional e Meio Ambiente - PPGDRA, BR 364, km 9,5, CEP 76800- \\ 000, Porto Velho, Rondônia, Brasil \\ Embrapa Rondônia, BR 364, km 5,5, Caixa Postal 127, CEP 76815-800, Porto Velho, Rondônia, Brasil \\ Universidade Federal de Rondônia - UNIR, Programa de Pós-graduação em Ciência Ambiental - PPGCA, Av. Norte Sul 7300, CEP 76940-000, Rolim de Moura, \\ Rondônia, Brasil \\ ${ }^{4}$ Universidade Federal de Pelotas (UFPel), Faculdade de Agronomia Elizeu Maciel - FAEM, Programa de Pós-graduação em Zootecnia (PPGZ), Campus Universitário, \\ s/n, CEP 96010-900, Capão do Leão, Rio Grande do Sul, Brasil \\ 5 Universidade Federal de Pelotas (UFPel), Faculdade de Veterinária, Caixa Postal 354, Campus Universitário, s/n, CEP 96010-900, Capão do Leão, Rio Grande do Sul, Brasil. \\ * Corresponding author: ana.salman@embrapa.br
}

\begin{abstract}
The relationship between the indices of thermal comfort and internal temperature in lactating cows was evaluated inRondônia, western Amazonia in a $2 \times 2$ crossover trial carried out with eight Girolando cows, $1 / 2$ Holstein $\times 1 / 2$ Gyr $(n=4)$ and 3/4 Holstein $\times 1 / 4 \operatorname{Gyr}(n=4)$, grazing palisade grass supplemented with or without soybean oil concentrates. Data logger thermometers adapted to intravaginal devices (hormone free) were used to measure internal temperatures (IT) every 10 min over $48 \mathrm{~h}$. Concomitantly, environmental parameters (air temperature, relative humidity, wind speed, and solar radiation) were collected for the estimation of the temperature-humidity index (THI), equivalent temperature index (ETI), and predicted respiratory rate (PRR). Supplementation with soybean oil did not affect the internal temperature of the cows. IT varied significantly between the genetic groups, with the highest mean observed at night in the $3 / 4$ Holstein $\times 1 / 4$ Gyr cows, compared with that in the $1 / 2$ Holstein $\times 1 / 2 \mathrm{Gyr}$ cows $\left(39.54^{\circ} \mathrm{C}\right.$ vs $39.06^{\circ} \mathrm{C}$, respectively). THI, ETI, and PRR were significantly and positively correlated with the IT of the Girolando cows; however, the PRR was not found to be adequate in indicating the night-time heat stress in cows.
\end{abstract}

KEYWORDS: heat stress, Holstein $\times$ Zebu, dairy cattle, environmental stress index

\section{Relação entre índices de estresse térmico e a temperatura interna de vacas Holandês x Gir lactantes em pastejo na Amazônia Ocidental}

\section{RESUMO}

A relação entre índices de conforto térmico com a temperatura interna de vacas lactantes foi avaliada em Rondônia, na Amazônia Ocidental, em um ensaio crossover $2 \times 2$ utilizando oito vacas Girolando, 1/2 Holandês x 1/2 Gir $(n=4)$ e 3/4 Holandês x 1/4 Gir $(\mathrm{n}=4)$ pastejando capim-marandu suplementadas com concentrados contendo ou náo óleo de soja. A temperatura interna (TI) dos animais foi aferida com termômetros eletrônicos adaptados em dispositivos intravaginais (livres de hormônio) a cada 10 minutos durante 48h. Concomitantemente, dados climáticos (temperatura do ar, umidade relativa do ar, velocidade do vento e radiação solar) foram coletados para cálculo dos índices de temperatura e umidade (ITU), índice de temperatura equivalente (ITE) e o índice de frequência respiratória predita (PFR). A suplementaçáo com óleo de soja não afetou a temperatura interna das vacas. A TI variou significativamente entre os grupos genéticos, com a maior média observada à noite nas vacas $3 / 4$ Holandês $\times 1 / 4$ Gir em relação às $1 / 2$ Holandês $\times 1 / 2$ Gir $\left(39,54^{\circ} \mathrm{C}\right.$ vs $39,06^{\circ} \mathrm{C}$, respectivamente). ITU, ITE e PFR tiveram correlação significativa e positiva com a TI de vacas Girolando, mas o PFR não foi adequado para indicar estresse térmico em vacas no período da noite.

PALAVRAS-ChAVE: estresse por calor, Holandês x Zebu, gado leiteiro, índice de estresse ambiental

CITE AS: Carvalho, G. A.; Salman, A. K. D.; Cruz, P. G.; Silva, F. R. F.; Halfen, J.; Schmitt, E. 2018. Relationship between thermal comfort indices and internal temperature of grazing lactating Holstein X Gyr cows in the western Amazonia. Acta Amazonica 48: 191-196. 


\section{INTRODUCTION}

Sustainability in livestock production systems is largely affected by climate. Climates with high air temperature and humidity cause heat stress in cows when the body's metabolic heat load exceeds its heat dissipation capacity. Currently, the main challenge facing the dairy industry is to overcome the negative effects of warm weather on herd performance (Polsky and von Keyserlingk 2017). The major bovine dairy breeds, including the most popular Holstein-Frisian, are originated in temperate climatic regions. These breeds suffer more from heat stress, partially because of their higher productivity, which reduces their thermal comfort threshold (Silva et al. 2002). The magnitude of heat stress is determined by the combined effects of high temperature and relative humidity, high incidence of solar radiation, and low wind speed, which increases the amount of energy the animals spend to dissipate their body heat (Souza and Batista 2012) and limits their growth, production, and reproductive efficiencies (Dash et al. 2016). It is possible to improve the thermal tolerance of animals through the use of genetic tools that combine the desirable characteristics of the European and Zebu breeds to produce crossbreeds. One such example is the Girolando, a result of crossbreeding between Holstein (European) and Gyr (Zebu), which is used mainly for dairy production in the grazing systems of tropical regions (Silva et al. 2014). Another strategy for improving dairy production under heat stress is the modification of diet composition to either promote a higher consumption or compensate for the low dry matter intake. This effect could be achieved by the addition of vegetable oil to the concentrate mixture, which raises the energy density without increasing the intake of non-structural carbohydrates (Wang et al. 2010).

The impact of heat stress on animal performance should be monitored through physiological parameters such as internal temperature and respiratory rate (Almeida et al. 2013). This is because one of the first visible signs of animals suffering from heat stress is an increase in their respiratory rate, which is a physiological mechanism that promotes heat loss via evaporation. The variation in the respiratory rate depends on the intensity and duration of the stress to which the animals are subjected.

However, there is still no practical methodology for measuring respiratory rate, especially in pasture-based dairy farms. Therefore, heat stress indices based on meteorological variables were developed to predict the impact of heat stress on livestock (Bohmanova et al. 2007). Such indices are useful to evaluate the general climate of an area; they involve local meteorological measurements, viz., of air temperature, humidity, wind speed, mean radiant temperature, and solar radiation, but the variables and their coefficients in a given index must be consistent with the physiological mechanisms of heat exchange of the animals (Silva et al. 2007).
The aim of the present study was to analyze some established thermal comfort indices with regards to their relationship with the internal temperature of grazing lactating Holstein $\times$ Gyr cows fed on diets with or without soybean oil supplementation and raised under the tropical environmental conditions of western Amazonia.

\section{MATERIAL AND METHODS}

All management practices applied to the experimental animals were approved by the Ethics Committee on Animal Use (CEUA) of Embrapa Rondônia (process number 03-2014).

The study was performed at an experimental field of Empresa Brasileira de Pesquisa Agropecuária (Embrapa) located in Porto Velho, Rondônia, Brazil $\left(8^{\circ} 47^{\prime} 38^{\prime \prime} S\right.$ and $\left.63^{\circ} 50^{\prime} 46^{\prime \prime} \mathrm{W}\right)$, from February to March 2015, during which the average temperature and precipitation were $25.75^{\circ} \mathrm{C}$ and $275.1 \mathrm{~mm}$, respectively. Mean temperature and precipitation were $26.69{ }^{\circ} \mathrm{C}$ and $184.8 \mathrm{~mm}$, respectively, during the day (from 06:00 to $17: 59$ ), and $24.83{ }^{\circ} \mathrm{C}$ and $90.3 \mathrm{~mm}$, respectively, during the night (from 18:00 to 5:59).

The predominant climate in this region is Am, which is characterized by a dry season from June to August and annual rainfall exceeding $2,250 \mathrm{~mm}$ (Alvares et al. 2014).

A $2 \times 2$ crossover trial was carried out over two 20-day experimental periods ( 10 days for diet adaptation and 10 days for data collection), totaling 40 days of trial. The cows were distributed between the treatments according to their average milk yield, genetic group, and mean of somatic cell count. The treatments involved supplementation with a concentrated mixture containing 7\% of soybean oil (on dry matter basis) and a concentrated mixture without soybean oil (Table 1). Eight multiparous lactating $1 / 2$ Holstein $\times 1 / 2$ Gyr $(\mathrm{n}=4)$ and $3 / 4$ Holstein $\times 1 / 4 \mathrm{Gyr}(\mathrm{n}=4)$ cows were used. They were in lactation for $53 \pm 33$ days, and had an average milk yield of $22.6 \pm 3 \mathrm{~kg} \mathrm{day}^{-1}$ and average live weight (LW) of $471 \pm 53 \mathrm{~kg}$. During the experimental period, the cows grazed on palisade grass (Urochloa brizantha 'Marandu') managed with intermittent stocking, with two days of occupation and 28 days of resting. The mean stocking rate was 2.5 Animal Unit ha ${ }^{-1}$ and the herbage mass was 3,830 $\mathrm{kg} \mathrm{DM} \mathrm{ha}^{-1}$ during the pre-grazing period.

The ingredients in the concentrate mixtures (Table 1) were balanced using the Cornell Net Carbohydrate and Protein System software (CNCPS v6.5.5). The amount of concentrate offered was adjusted weekly according to each cow's yield, at the rate of one kg per three $\mathrm{kg}$ of milk produced above the average daily production of eight $\mathrm{kg}$. The concentrate was supplied individually in two equal meals during milking (at 7:30 and at 1:30). Soybean oil was added and mixed to the concentrate just before the meals. 
Table 1. Ingredient composition, chemical composition, and in vitro dry matter digestibility (IVDMD) of concentrate mixtures and palisade grass (Urochloa brizantha 'Marandu') forage

\begin{tabular}{lccc}
\hline & \multicolumn{2}{c}{ Concentrate Mixture (\% DM) } & \multirow{2}{*}{ Forage } \\
\cline { 2 - 3 } & Control & Soybean Oil & \\
\hline Ingredient composition* & & & \\
\hline Soybean meal & 43.75 & 48.78 & - \\
Corn meal & 50.00 & 37.28 & - \\
\hline Mineralized salt & 4.69 & 5.23 & - \\
\hline Urea & 1.56 & 1.74 & - \\
\hline Soybean oil & - & 6.97 & - \\
\hline Total & 100.00 & 100.00 & - \\
\hline Chemical composition & & & \\
\hline Dry matter (\%) & 88.29 & 88.11 & 29.51 \\
\hline Ash (\% DM) & 9.94 & 8.05 & 5.49 \\
\hline Crude Protein, CP (\% DM) & 31.32 & 31.5 & 8.08 \\
\hline Ether Extract, EE (\% DM) & 0.89 & 5.07 & 1.63 \\
\hline NDF (\% DM) & 10.20 & 10.7 & 59.77 \\
\hline ADF (\% DM) & 5.01 & 3.31 & 30.04 \\
\hline Lignin (\% DM) & 0.83 & 0.92 & 3.75 \\
\hline Cellulose (\% DM) & 4.18 & 4.39 & 26.29 \\
\cline { 1 - 2 } Hemicellulose (\% DM) & 5.19 & 5.39 & 29.73 \\
\hline IVDMD (\% DM) & 88.6 & 85.08 & 66.67 \\
\hline
\end{tabular}

*Requirements for a dairy cow producing $15 \mathrm{~kg}$ milk day ${ }^{-1}$ (National Requirement Council, 2001).

NDF: Neutral Detergent Fiber, ADF: Acid Detergent Fiber

The internal temperature of the animals was recorded using iButton ${ }^{\circledR}$ thermometers (DS1921H-F5\# Thermochron, Innovation Drive Whitewater, WI 53190 United States) programmed for data recording every $10 \mathrm{~min}$ over $48 \mathrm{~h}$. Thermometers were adapted to hormone-free intravaginal devices (CIDR $\AA)$.

The temperature-humidity index (THI) was calculated by the equation of Thom (1959):

$$
\mathrm{THI}=\mathrm{Tdb}+0.36 \mathrm{Tdp}+41.2
$$

where $\mathrm{Tdb}=$ dry bulb temperature $\left({ }^{\circ} \mathrm{C}\right)$ and $\mathrm{Tdp}=$ dew point temperature $\left({ }^{\circ} \mathrm{C}\right)$.

The equivalent temperature index (ETI) was estimated by Baeta equation (Silva et al. 2007):

$$
\begin{gathered}
\text { ETI }=27.88-(0.456 \mathrm{Ta})+\left(0.010754 \mathrm{Ta}^{2}\right) \\
-\left(0.4905 \mathrm{Rh}^{2}\right)+(1.1507 \mathrm{~V})-\left(0.126447 \mathrm{~V}^{2}\right) \\
+(0.019876 \mathrm{TaRh})-(0.046313 \mathrm{TaV})
\end{gathered}
$$

where $\mathrm{Ta}=$ dry bulb temperature $\left({ }^{\circ} \mathrm{C}\right), \mathrm{Rh}=$ relative humidity $(\%)$, and $\mathrm{V}=$ wind speed $\left(\mathrm{m} \mathrm{s}^{-1}\right)$.
The predicted respiratory rate (PRR) was calculated using the Eigenberg equation (Silva et al. 2007):

$$
P R R=(5.4 T a)+(0.58 R h)-(0.63 V)+(0,024 S)-110.0
$$

where $\mathrm{Ta}=$ dry bulb temperature $\left({ }^{\circ} \mathrm{C}\right), \mathrm{Rh}=$ relative humidity $(\%), \mathrm{V}=$ wind speed $\left(\mathrm{m} \mathrm{s}^{-1}\right)$, and $\mathrm{S}=$ solar radiation. This equation was developed for animals exposed to sunlight with no shading. Thus, for nighttime data, the parameter $S$ was considered null.

Environmental parameters (dry bulb temperature, dew point temperature, relative humidity, wind speed, and solar radiation) were obtained from a weather station located approximately $800 \mathrm{~m}$ from the experimental area. All data were available on the Inmet website (http://www.inmet.gov. $\mathrm{br} /$ sonabra/maps/automaticas).

Statistical analysis was performed using the Mixed Procedure (PROC MIXED) of the Statistical Analysis System (SAS) software, where diet supplementation (with or without oil addition), genetic groups (1/2 Holstein $\times 1 / 2$ Gyr and $3 / 4$ Holstein $\times 1 / 4$ Gyr), time of the day (day and night), and experimental periods were considered as fixed effects while the cows were considered as random effects. The correlation equations were generated and tested ( $t$-test at $1 \%$ probability) using the regression procedure (PROC REG) of SAS.

\section{RESULTS}

There was no effect of soybean oil supplementation on the internal temperatures (IT) of the lactating Girolando cows. However, when genetic groups were compared, regardless the period of the day, the $3 / 4$ Holstein $\times 1 / 4$ Gyr cows had higher IT than the $1 / 2$ Holstein $\times 1 / 2$ Gyr cows $\left(39.45^{\circ} \mathrm{C}\right.$ vs. $39.06^{\circ} \mathrm{C}$, respectively). The interaction between genetic group and time of the day (Table 2 ) showed that $3 / 4$ Holstein $\times 1 / 4$ Gyr cows had higher IT at night than during the day. The $3 / 4$ Holstein $\times 1 / 4$ Gyr cows also had higher IT at night compared with that of the $1 / 2$ Holstein $\times 1 / 2$ Gyr cows, but the mean values were similar between both the genetic groups during the day.

The average values of the indices were: THI 75.11 (73.69 and 76.52 during night and day, respectively), ETI 31.63

\begin{tabular}{|c|c|c|c|}
\hline \multirow{2}{*}{ Genetic Group } & \multicolumn{2}{|c|}{ Period } & \multirow{2}{*}{ Standard Error } \\
\hline & Day & Night & \\
\hline $1 / 2 \mathrm{H} \times \mathrm{G}$ & $39.05 \mathrm{Bb}$ & $39.07 \mathrm{Bb}$ & 0.0885 \\
\hline $3 / 4 \mathrm{H} \times \mathrm{G}$ & $39.37 \mathrm{Bb}$ & $39.54 \mathrm{Aa}$ & 0.0884 \\
\hline $\mathrm{Pr}$ & \multicolumn{2}{|c|}{0.0007} & \\
\hline
\end{tabular}
(29.43 and 32.34 during night and day, respectively), and PRR 83 (72 and 94 during night and day, respectively).

Table 2. Means of internal temperature $\left({ }^{\circ} \mathrm{C}\right)$ of lactating Holstein $\times \mathrm{Gyr}(\mathrm{H} \times \mathrm{G})$ cows within genetic groups and period of the day

Means followed by the same upper-case letter in the column or lower-case letter in the row do not differ significantly, according to Tukey's test $(P<0.05)$ 
All indices had positive correlation with the IT of Girolando cows (Table 3), i.e., the indices increased with the increase in the internal temperatures of the cows. Equations for IT prediction as a function of the thermal stress indices (Table 4, Figure 1) were different between the genetic groups, with higher predicted IT for the $3 / 4$ Holstein $\times 1 / 4$ Gyr cows compared with that of the $1 / 2$ Holstein $\times 1 / 2$ Gyr cows during both periods (day and night).

Higher correlation coefficients between cow IT and environmental indexes were found during the day than at night, with the highest correlation observed for THI. The index that showed the lowest correlation with cow IT was the PRR at night (Table 3).

Table 3. Correlation coefficients between temperature-humidity index (THI), equivalent temperature index (ETI), and predicted respiratory rate (PRR) and the internal temperature of the lactating Holstein $\times \mathrm{Gyr}(\mathrm{H} \times \mathrm{G})$ cows during the day (06:00-17:59) and night (18:00-05:59

\begin{tabular}{|c|c|c|c|c|}
\hline Index & Genetic Group & Period & Correlation & Observations \\
\hline \multirow{4}{*}{ THI } & \multirow{2}{*}{$1 / 2 \mathrm{H} \times \mathrm{G}$} & Day & $0.5340 * * *$ & 458 \\
\hline & & Night & $0.4127^{* * *}$ & 480 \\
\hline & \multirow{2}{*}{$3 / 4 \mathrm{H} \times \mathrm{G}$} & Day & $0.5603^{* * *}$ & 460 \\
\hline & & Night & $0.4529 * * *$ & 480 \\
\hline \multirow{4}{*}{ ETI } & \multirow{2}{*}{$1 / 2 \mathrm{H} \times \mathrm{G}$} & Day & $0.5554^{* * *}$ & 459 \\
\hline & & Night & $0.3436^{* * *}$ & 480 \\
\hline & \multirow{2}{*}{$3 / 4 \mathrm{H} \times \mathrm{G}$} & Day & $0.5296^{* * *}$ & 460 \\
\hline & & Night & $0.4211^{* * *}$ & 480 \\
\hline \multirow{4}{*}{ PRR } & \multirow{2}{*}{$1 / 2 \mathrm{H} \times \mathrm{G}$} & Day & $0.4522^{* * *}$ & 459 \\
\hline & & Night & $0.2602^{* * *}$ & 480 \\
\hline & \multirow{2}{*}{$3 / 4 \mathrm{H} \times \mathrm{G}$} & Day & $0.4143^{* * *}$ & 460 \\
\hline & & Night & $0.3807^{* * *}$ & 480 \\
\hline
\end{tabular}

***Significant at $\mathrm{P}<0.0001$

Table 4. Regression equations for prediction of internal temperature (IT) of lactating Holstein $\times \mathrm{Gyr}(\mathrm{H} \times \mathrm{G})$ cows as a function of the temperature humidity index (THI), predicted respiratory rate (PRR), and equivalent temperature index (ETI) during the day (06:00 to 17:59) and night (18:00 to 05:59).

\begin{tabular}{|c|c|c|c|c|}
\hline Index & Period & Genetic Group & Equations & $r^{2}$ \\
\hline \multirow{4}{*}{$\mathrm{THI}$} & \multirow{2}{*}{ Day } & $3 / 4 \mathrm{H} \times \mathrm{G}$ & $\mathrm{IT}=0.1285^{* *} \mathrm{THI} \_$Day+29.66** & 0.3139 \\
\hline & & $1 / 2 \mathrm{H} \times \mathrm{G}$ & $\mathrm{IT}=0.1057^{* *} \mathrm{THI} \_$Day+31.06** & 0.2853 \\
\hline & \multirow{2}{*}{ Night } & $3 / 4 \mathrm{H} \times \mathrm{G}$ & $\mathrm{IT}=0.077^{* *} \mathrm{THI} \_N i g h t+33.63^{* *}$ & 0.2052 \\
\hline & & $1 / 2 H \times G$ & $\mathrm{IT}=0.071^{* *} \mathrm{THI}$ Night $+33.64^{* *}$ & 0.1703 \\
\hline \multirow{4}{*}{ PRR } & \multirow{2}{*}{ Day } & $3 / 4 \mathrm{H} \times \mathrm{G}$ & 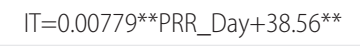 & 0.1717 \\
\hline & & $1 / 2 H \times G$ & $\mathrm{IT}=0.00738^{* *}$ PRR_Day+38.29** & 0.2045 \\
\hline & \multirow{2}{*}{ Night } & $3 / 4 \mathrm{H} \times \mathrm{G}$ & 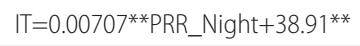 & 0.1449 \\
\hline & & $1 / 2 H \times G$ & 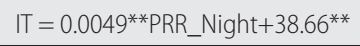 & 0.0677 \\
\hline \multirow{4}{*}{ ETI } & \multirow{2}{*}{ Day } & $3 / 4 \mathrm{H} \times \mathrm{G}$ & $\mathrm{IT}=0.10383^{* *} \mathrm{ETI} \_D a y+36.07^{* *}$ & 0.2805 \\
\hline & & $1 / 2 H \times G$ & $\mathrm{IT}=0.09446^{* *} \mathrm{ETI} \_D a y+36.05^{* *}$ & 0.3085 \\
\hline & \multirow{2}{*}{ Night } & $3 / 4 \mathrm{H} \times \mathrm{G}$ & $\mathrm{IT}=0.06920^{* *} \mathrm{ETI}$ Night+37.32** & 0.1774 \\
\hline & & $1 / 2 H \times G$ & $\mathrm{IT}=0.05717^{* *} E T I \_N i g h t+37.26^{* *}$ & 0.1181 \\
\hline
\end{tabular}

**Significant $(t$-test) $(\mathrm{P}<0.01)$

\section{DISCUSSION}

Supplementation with licuri palm oil had no effect on the rectal temperature of lactating Girolando cows (Borja et al. 2009) in agreement with our findings in the present study. The observed mean of internal temperature in the studied cows $\left(39.25^{\circ} \mathrm{C}\right)$ was within the normal range, considering that a healthy dairy cow maintains its core body temperature between $38.0^{\circ} \mathrm{C}$ and $39.3{ }^{\circ} \mathrm{C}$ (Robinson 1999).

Regarding the differences in the internal temperature between the genetic groups, Dalcin et al. (2016) also found differences between the rectal temperature of $3 / 4$ Holstein $x$ $1 / 4$ Gyr and $1 / 2$ Holstein $\times 1 / 2$ Gyr cows $\left(39.39^{\circ} \mathrm{C}\right.$ vs. 39.01 ${ }^{\circ} \mathrm{C}$, respectively). The $1 / 2$ Holstein crossbred cows are more thermotolerant than $3 / 4$ Holstein cows under conditions of heat stress (Costa et al. 2015). The inability of the $3 / 4$ Holstein $\times 1 / 4$ Gyr cows to dissipate body heat as efficiently as the $1 / 2$ Holstein $\times 1 / 2$ Gyr cows could be explained by the fact that Zebu breeds can regulate their body temperature better than the European breeds, in response to heat stress (Dalcin et al. 2016). It is well established that Bos indicus and Bos taurus regulate body temperature, including rumen temperature, differently (Lees et al. 2018).

Based on rectal temperatures, Azevedo et al. (2005) estimated the upper critical THI values of 80 and 77 for $1 / 2$ and $3 / 4$ Girolando cattle, respectively. Considering the observed THI means during the experimental period, the THI was near the upper critical value for the $3 / 4$ Holstein $x$ $1 / 4$ Gyr cows when compared with that for $1 / 2$ Holstein $\times 1 / 2$ Gyr cows, especially during the day.

Zebu breeds have lower metabolic rates as well as higher capacity for heat loss, which are some of the reasons that explain their great capacity of thermoregulation during heat stress caused by environmental conditions. When compared with European breeds, tissue resistance to heat flow from the body core to the skin is lower in Zebu cattle and their sweat glands are larger. Moreover, the hair coat in Zebu cattle enhances conductive and convective heat loss and reduces absorption of solar radiation (Dikmen and Hansen 2009).

Higher internal temperature was found in the $3 / 4$ Holstein $\times 1 / 4$ Gyr cows during the night. This result could be explained by the fact that under high temperature, cattle tend to reduce their activities, especially grazing, during the day, resuming such activities at dusk when the temperatures are lower (Zanine et al. 2007). Salla et al. (2009) reported higher grazing activity of the Girolando heifers during late afternoon (from 17:00 to 18:00). Consequently, internal temperature tends to be higher during the night, when the animals intensify their feeding activities, generating heat from both physical movements, viz., grazing, and from the digestion process (Costa et al. 2015). 

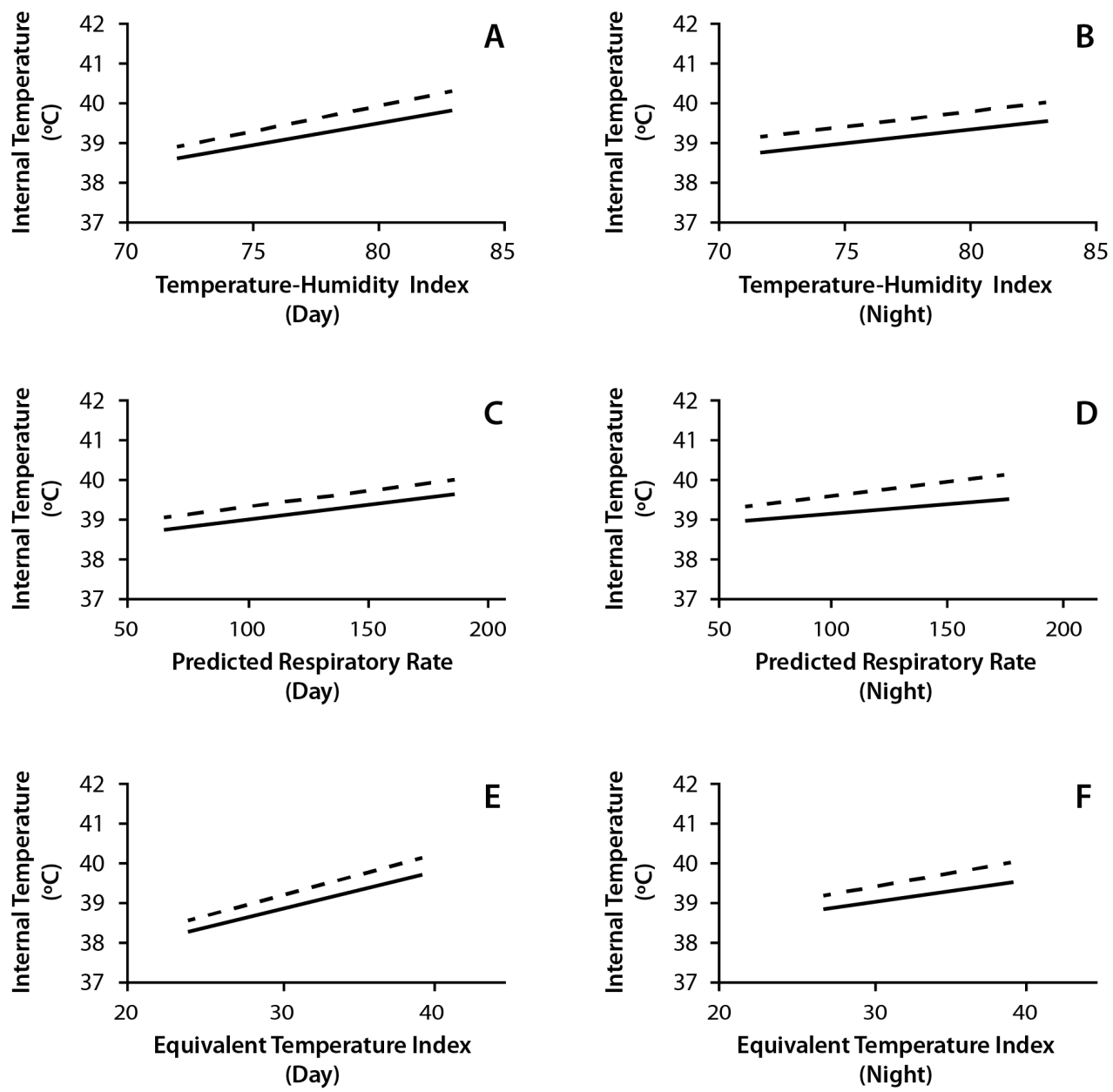

Figure 1. Equations for $1 / 2$ Holstein $\times$ Gyr $(H \times G)$ cows (solid line) and $3 / 4 \mathrm{H} \times \mathrm{G}$ cows (dotted line) for internal temperature prediction as a function of temperaturehumidity index (THI) during the day (A) and at night (B), equivalent temperature index (ETI) during the day (C) and at night (D), and predicted respiratory rate (PRR) during the day (E) and at night (F). The daytime was from 06:00 to 17:59 and nighttime was from 18:00 to 05:59.

The low values of the determination coefficient $\left(r^{2}\right)$ may be related to animal homeostasis events. When the body temperature is significantly elevated because of increases in the environmental temperature, a myriad of homeothermic events start to maintain body temperature within the normal range (Robinson 1999).

The THI has been frequently used to evaluate the environment of livestock systems, mainly in the tropical regions, despite its limitations (Silva et al. 2007). The THI inherently does not account for the effects of solar radiation (SR) and low air speed (WS) to which the animals are exposed, especially in pasture-based dairy production.

Silva et al. (2007) compared six heat stress indices based on their correlation with the rectal temperatures of Holstein and Jersey dairy cows in a tropical environment, and found no correlation between rectal temperature and THI. This is in contrast with the findings of our study, probably because of the differences in the methodologies used for measuring animal temperature. In the present study, data logger thermometers were used, with internal temperature recorded every $10 \mathrm{~min}$ over $48 \mathrm{~h}$, while Silva et al. (2007) measured rectal temperature of the cows only once a day after exposure to sunlight (from 9 to 11:20).

The PRR index showed the lowest correlation with the IT of Girolando cows during night. This result was expected considering that one of the variables used in the PRR equation is solar radiation (S), which does not occur during the night. In the Eigenberg equation for analyzing nighttime data, $S$ was considered null. Thus, the calculated PRR for this period of the day may be underestimated. In future studies, the equations for shade and no-shade situations proposed by Eigenberg et al. (2005) need to be considered.

Silva et al. (2007) also found correlation between PRR and rectal temperature measured once a day in cows after exposure to sunlight from 09:00 to 11:20, but the correlation coefficient (0.114) was lower than that found in this study (Table 3), probably because of our greater number of IT observations. 


\section{CONCLUSIONS}

Under the study conditions in western Amazonia, oil supplementation does not change the internal temperature of lactating Girolando cows experiencing heat stress. The $1 / 2$ Holstein $\times 1 / 2$ Gyr cows are more thermotolerant than the $3 / 4$ Holstein $\times 1 / 4$ Gyr cows. The temperature-humidity index (THI), equivalent temperature index (ETI), and predicted respiratory rate (PRR) are positively correlated with the internal temperature of the lactating Girolando cows, but the PRR is not adequate in indicating the nighttime thermal stress in dairy cows.

\section{ACKNOWLEDGMENTS}

The study received financial support from Conselho Nacional de Desenvolvimento Científico e Tecnológico - CNPq (process \# 478318/2013-8).

\section{REFERENCES}

Almeida, G.L.P.; Pandorfi, H.; Barbosa, S.B.; Pereira, D.F.; Guiselini, C.; De Almeida, G.A. 2013. Comportamento, produção e qualidade do leite de vacas Holandês-Gir com climatização no curral. Revista Brasileira de Engenharia Agricola e Ambiental, 17: 892-899.

Alvares, C.A.; Stape, J.L.; Sentelhas, P.C.; De Moraes, G.; Leonardo, J.; Sparovek, G. 2014. Koppen's climate classification map for Brazil. Meteorologische Zeitschrift, 22: 711-728.

Azevedo, M.; Pires, M.F.A.; Saturnino, H.M.; Lana, A.M.Q.; Sampaio, I.B.M.; Monteiro, J.B.N.; Morato, L.E. 2005. Estimativa de níveis críticos superiores do índice de temperatura e umidade para vacas leiteiras 1/2, 3/4, 7/8 Holandês-Zebu em lactação. Revista Brasileira de Zootecnia, 34: 2000-2008.

Bohmanova, J.; Misztal, I.; Cole, J.B. 2007. Temperature-humidity indices as indicators of milk production losses due to heat stress. Journal of Dairy Science, 90: 1947-1956.

Borja, M.S.; Garcez Neto, A.F.; Oliveira, R.L.; Lima, L.S.; Bagaldo, A.R.; Barbosa, L.P.; Faria, E.F.S. 2009. Óleo de licuri no concentrado administrado a vacas Holandesas x Zebu, sobre o comportamento ingestivo e conforto térmico. Revista Brasileira de Saúde e Produção Animal, 10: 344-355.

Costa, A.N.L.; Feitosa, J.V.; Montezuma Júnior, P.A.; Souza, P.T; Araújo, A.A. 2015. Rectal temperatures, respiratory rates, production, and reproduction performances of crossbred Girolando cows under heat stress in northeastern Brazil. International Journal Biometeorology, 59: 1647-1653.

Dalcin, V.C., Fischer, V., Daltro, D.D.S., Alfonzo, E.P.M., Stumpf, M.T., Kolling, G.J., Mcmanus, C. 2016. Physiological parameters for thermal stress in dairy cattle. Revista Brasileira de Zootecnia, 45: 458-465.

Dash, S.; Chakravarty, A.K.; Singh, A.; Upadhyay, A.; Singh, M.; Yousuf, S. 2016. Effect of heat stress on reproductive performances of dairy cattle and buffaloes: A review. Veterinary World, 9: 235-244.
Dikmen, S.; Hansen, P.J. 2009. Is the temperature-humidity index the best indicator of heat stress in lactating dairy cows in a subtropical environment? Journal of Dairy Science, 92: 109-116.

Du Preez, J.H. 2000. Parameters for determination and evaluation of heat stress in dairy cattle in South Africa. Onderstepoort Journal of Veterinary Research, 67: 263-271.

Eigenberg, R.A.; Brown-Brandl, T.M.; Nienaber, J.A.; Hahn, G.L. 2005. Dynamic response indicators of heat stress in shaded and non-shaded feedlot cattle, Part 2: Predictive relationships. Engineering in Agriculture, 91: 111-118.

Lees, A.M.; Lees, J.C.; Lisle, A.T.; Sullivan, M.L.; Gaughan, J.B. 2018. Effect of heat stress on rumen temperature of three breeds of cattle. International Journal Biometeorology, 62: 207-215.

National Requirement Council. 2001. Nutrient requirements of dairy cattle. $7^{\text {th }}$ ed. National Academy Press, Washington, D.C, 408p.

Polsky, L.; von Keyserlingk, M.A.G. 2017. Invited review: Effects of heat stress on dairy cattle welfare. Journal of Dairy Science, 100: 8645-8657.

Robinson, E.N. 1999. Termorregulação. In: Cunningham, J.G. Tratado de fisiologia veterinária. 2.ed. Guanabara-Koogan, Rio de Janeiro, Rio de Janeiro, cap.51, p.427-435.

Salla, L.; Pires, M.F.A.; Morais, D.; Dias, M.; Oliveira, P.; Santos, B.C. 2009. Efeito da disponibilidade de sombra sobre o conforto térmico de novilhas leiteiras. Revista Brasileira de Agroecologia, 4: 3343-3346.

Silva, I.J.O.; Pandorf, H.; Arcaro Jr., I.; Piedade, S.M.S.; Moura, D.J. 2002. Efeitos da climatização do curral de espera na produção de leite de vacas holandesas. Revista Brasileira de Zootecnia, 31: 2036-2042.

Silva, J.B.; Fagundes, G.M.; Soares, J.P.G.; Fonseca, A.H.; Muir, J.P.A. 2014. Comparative study of production performance and animal health practices in organic and conventional dairy systems. Tropical Animal Health Production, 46: 1287-1295.

Silva, R.G.D.; Morais, D.A.E.F; Guilhermino, M.M. 2007. Evaluation of thermal stress Indices for dairy cows in tropical regions. Revista Brasileira de Zootecnia, 36: 1192-1198.

Souza, B.B.; Batista, N.L. 2012. Os efeitos do estresse térmico sobre a fisiologia animal. Agropecuária Cientifica no Semi-Árido, 8: 6-10.

Thom, E.C. 1959. The discomfort index. Weatherwise, 12: 57-61.

Wang, J.P.; Bu, D.P.; Wang, J.Q.; Huo, X.K.; Guo, T.J.; Wei, H.Y; Li, F.D. 2010. Effect of saturated fatty acid supplementation on production and metabolism indices in heat-stressed midlactation dairy cows. Journal of Dairy Science, 93: 4121-4127.

Zanine, A.M.; Vieira, B.R.; Ferreira, D.J.; Vieira, A.J.M.; Cecon, P.R. 2007. Comportamento ingestivo de bovinos de diferentes categorias em pastagem de capim coast-cross. Bioscience Journal, 23: 111-119.

RECEIVED: $13 / 12 / 2017$

ACCEPTED: $25 / 04 / 2018$

ASSOCIATE EDITOR: Rodrigo do Valle 